\title{
Gene Expression Changes and Signal Transduction Pathway Alterations in Primary Human Oral Epithelial Cells Exposed to Smokeless Tobacco Extracts
}

\author{
Rohan Rajapakse, Annesha Basu, Sanam Shahid, Michael P. Timko* \\ Department of Biology, University of Virginia, Charlottesville, VA, USA \\ Email: ${ }^{*}$ mpt9g@virginia.edu
}

Received 27 September 2014; revised 26 October 2014; accepted 7 November 2014

Academic Editor: Jiban Shrestha, Nepal Agricultural Research Council, National Maize Research Program, Nepal

Copyright (C) 2014 by authors and Scientific Research Publishing Inc.

This work is licensed under the Creative Commons Attribution International License (CC BY). http://creativecommons.org/licenses/by/4.0/

(c) (i) Open Access

\section{Abstract}

Smokeless tobacco (ST), an alternative to smoking, has gained wide popularity among tobacco users. This study is conducted to determine the time course of gene expression associated with specific signaling pathways in human oral epithelial cells after exposure to smokeless tobacco extract (STE). A differentiated layer of epithelial cell is created as a way to mimic reasonably similar physiological atmosphere. A dose and time dependent response is observed for cell viability and cell proliferation assays indicating that this model system is responsive to the treatment. Expressions of 84 genes representing 18 different signal transduction pathways are quantitated. This is accomplished by using real-time polymerase chain reaction arrays at $1 \mathrm{~h}, 3 \mathrm{~h}, 6 \mathrm{~h}$ and $24 \mathrm{~h}$ time points following exposure to STE. Changes in gene expression are observed on many cellular processes including cell cycle regulation, cell adhesion, inflammation, apoptosis, and DNA breaksdown including Akt pathway activation. Short time exposure $(1 \mathrm{~h})$ leads more genes to down regulate whereas longer incubation time results in more genes up regulation. Most notable differences in the expression of genes during the course of treatment are BCL2A1, BIRC3, CCL20, CDK2, EGR1, FOXA2, HOXA1, IGFBP3, IL1A, IL-8, MMP10, NOS2, NRIP1, PTGS2, SELPLG and TNF-a. This study provides an insight on gene expression on oral epithelial cells as a result of STE exposure. This may also postulate greater understanding on biological effects and the mechanism of action of STE particularly at the transcriptional level.

\footnotetext{
${ }^{*}$ Corresponding author.
} 


\section{Keywords}

\section{Apoptosis, Primary Oral Epithelial Cells, RT-PCR Array, Smokeless Tobacco Extract (STE), Transcriptome}

\section{Introduction}

There is a global increase in the incidence and mortality rate of head and neck cancer [1]. The social habit of tobacco use is implicated as the major factor involved in the etiology of the disease [2] [3]. Smokeless tobacco (ST) is mainly used orally as an alternative to cigarette smoking and its use in the US has been persistent in the recent past [4]. ST is not only an addictive agent, but it also has levels of nicotine and other ingredients comparable to conventional cigarettes [5]. More than 30 carcinogens exist in ST, including volatile and tobacco-specific nitosamines, nitrosamino acids, polycyclic aromatic hydrocarbons, aldehydes and metals [6]. Epidemiological and meta-analysis suggested an increase of health risk for cancer and cardiovascular diseases with the use of ST products [6] [7]. Surprisingly, little is known about the mechanistic basis leading to the disease occurrence. That is partly due to both for not having a well-defined model system and dynamic nature of chemical constitutes in the mixture. A better understanding of the response mechanism may help uncover relevant biomarkers in developing potentially reduced exposure products (PREPs).

ST associated health risks have been reported in the recent past. Exposure to STE enhances buccal mucosal injury and inflammation in human subjects leading to the development of dysplasia in the oral epithelium [8]. Carcinogens in ST products have been shown to form adducts with both DNA and hemoglobin, which enhances the risk of cancer development [3]. Use of ST has been attributed to an increased risk for atherosclerosis [4], hypertension [9], myocardial infarction [7], stroke [10], and diabetes mellitus [11]. Oxidative stress as a result of enhanced production of reactive oxygen species (ROS) and reactive nitrogen species plays an important role in STE-induced cell death [12]. Similarly exposure to STE increases the production of pro-inflammatory cytokines that are suggested to be associated with induction of periodontal disease [13]. The activation of endothelium and the increase in neutrophil transmigration as a result of STE exposure are suggested to be associated with the induction of atherosclerosis [14]. Previous reports indicated an increase in the induction of apoptosis by STE in a variety of cell types [15] [16]. Interestingly, STE induced toxicity leading to cell death is attributed to apoptosis on various oral cell types, including oral keratinocytes, hamster cheek pouch cells, and EBV-infected B cells [16]-[18]. However, an understanding of the molecular mechanism (s) leading to STE-induced apoptosis at the transcription level is minimal. STE increases up-regulation of pro-inflammatory protein, COX-2 on cell types derived from primary human cancer tissues [8]. STAT-5 and Cyclin D1 expression has been observed in oral squamous cell carcinomas exposed to STE indicating an activation of STAT5-Cyclin D1 pathway [19] [20]. Further, an activation of STAT-3 was shown in head and neck cancer [21]. Cell cycle regulatory proteins p53, p21waf1/cip1 and proliferation marker Ki67 including transcription factor Ets-1 and NF- $\mathrm{B}$ were differentially altered in premalignant lesion in the oral cavity of long-term users of ST [22] [23].

Despite previous studies highlighting the health risk associated with use of ST, a comprehensive studies focusing on its biological effects and cellular responses at transcriptional level are limited. Therefore, the purpose of this study was to investigate the effects of exposure to STE on human oral epithelial cell function. To accomplish this we monitored the simultaneous expression of 84 genes involved in 18 signal transduction pathways as a result of exposure to non-lethal dose of STE using a quantitative real-time polymerase chain reaction (qRTPCR) based platform. Further, we have created a model system for human exposure studies by creating a differentiated epithelial cell layer to mimic reasonably similar biological tissue in the mouth. Combined technologies such as microarray and qRT-PCR analysis enable researchers to simultaneously study multiple genes involved in specific pathways [24]. A successful strategy for analyzing the mechanistic basis of cellular changes will require targeting several pathways at once.

\section{Materials and Methods}

\subsection{Cell Culture}

Progenitor cells isolated from human oral gingival tissue were purchased (ZenBio, NC) and maintained as pri- 
mary human oral epithelial cells (HOEP) on serum-free defined media (CNT-24, ZenBio, NC) following manufacturer's instructions. To induce differentiation, cells were seeded in 6 well plates (Corning, NY) at $3 \times 10^{4}$ cells in CNT-24 media as submerged cultures. Once cells reached $80 \%$ to $85 \%$ confluence, replaced with CNT-32 (a defined media, ZenBio, NC) followed by feeding cells every other day with calcium enriched media (CNT-32 with $1.2 \mathrm{mMol}$ of calcium chloride (GIBCO, NY)) for 7 days as instructed by the supplier. Two to three days after transferring into high calcium media, cells were visibly less proliferative and flattened whereas control cells remain committed to their characteristic appearance (cobblestone). The status of cell differentiation was evaluated both morphologically and biochemically during the course of differentiation. Involucrine, a differentiation marker, was analyzed at protein level by immunocytochemistry and RNA level by quantitative PCR. Cultures are taken for experiments at day 7 of differentiation, unless otherwise indicated.

\subsection{Experimental Design}

Cells at day 7 of differentiation were taken for experiments. For gene expression analysis, cells were treated with $10 \mathrm{mg} / \mathrm{ml}$ of smokeless tobacco extract (STE) for indicated time points whereas control samples were mock treated. At the end of the incubation, the treatment cells and control cells were decanted followed by two washes of cells with PBS. Three independent experiments were conducted for each exposure condition.

\subsection{Isolation of Smokeless Tobacco Extract}

Smokeless tobacco (moist snuff) extract (STE) was prepared by using research grade reference 1S3 moist snuff (a kind gift from Dr. David Danehower, North Carolina State University) as described in the literature [18]. Briefly, $10 \mathrm{~g}$ of smokeless tobacco was mixed with $100 \mathrm{ml}$ of basal medium (CNT-32, ZenBio, NC). After incubation for $2 \mathrm{~h}$ at $37^{\circ} \mathrm{C}$, the suspension was centrifuged at $450 \mathrm{~g}$ for $10 \mathrm{~min}$. The supernatant was subject to ultracentrifugation in a Sorvall centrifuge (SA-600 rotor) at 13,000 g for $1 \mathrm{~h}$ at $4^{\circ} \mathrm{C}$. The ultra-centrifuged supernatant was adjusted to PH 7.4 with $0.1 \mathrm{~N}$ hydrochloric acid and sterilized by filtration through $0.22 \mu \mathrm{m}$ filter (Millipore) and immediately stored $-80^{\circ} \mathrm{C}$ as $2 \mathrm{ml}$ aliquots. The sterile extract was named $10 \%$ STE based on weight/volume ratio. The $10 \%$ STE was further diluted with the culture medium to indicated concentrations.

\subsection{Immunocytochemistry}

Cells were grown on coverslips in 6 well plates (Corning, NY). When they reached the appropriate time points, they were washed two times with PBS, fixed with $80 \%$ ice-cold methanol for involucrin (Abcam, MA), and permeabilized with $0.5 \% \mathrm{v} / \mathrm{v}$ Triton for $10 \mathrm{~min}$ at room temperature. After three washes with PBS, the cells were blocked for $1 \mathrm{~h}$ with PBS containing 2\% w/v BSA plus 5\% v/v calf serum, and then incubated at $4{ }^{\circ} \mathrm{C}$ overnight with primary antibody. Cells were washed three times with PBS and incubated for $1 \mathrm{~h}$ at room temperature in a dark room with secondary antibody. For negative controls, the same procedure was performed without adding primary antibody. Nuclei were counterstained with $0.5 \mathrm{ng} / \mathrm{ml}$ 4'6-diamidino 2-phenylindole (DAPI). Slides were then mounted with fluoromount-G (SouthernBiotech, AL) and examined using a Leica confocal microscopy (SP5X, Wetzlar, Germany).

\subsection{Neutral Red Cytotoxicity Assay}

The Neutral Red Cytotoxicity Assay (NR assay) was used to assess the viability of cells after exposure to STE. The protocol for NR assay was based on guidelines set in 2001 by the National Institute of Health on using in vitro data to estimate in vivo starting doses for acute toxicity). Briefly, the culture medium was removed from the wells (96 well plate) and replaced with neutral red solution ( $0.05 \mathrm{~g} / \mathrm{l}$, sigma-Aldrich, MO). The cultures were incubated with neutral red solution for $3 \mathrm{~h}$ at $37^{\circ} \mathrm{C}$ to allow uptake of the dye into viable cells. The wells were then washed thoroughly with PBS to ensure complete removal of unincorporated dye. The natural red was eluded from the cells by placing $250 \mu \mathrm{l}$ of distilled water containing $50 \%$ ethanol and $1 \%$ acetic acid (vol:vol) into each well. Elutes were read on a microplate reader (Multiskan EX, Thermo Scientific, Waltham, MA) at $540 \mathrm{~nm}$ using a reference filter of $620 \mathrm{~nm}$. Blank wells were included in the study to establish background levels of dye that were adsorbed onto the well matrix in the absence of cells. These background measurements were subsequently subtracted from those of the treated and untreated control cultures. Neutral Red uptake from the treatment was compared with that of the controls to calculate the percentage of cell viability relative to the con- 
trols.

\subsection{Cell Proliferation Assay (BRDU)}

Cell proliferation was determined by 5-bromodeoxyuridine (BRDU) incorporation following manufacturer's instructions (Millipore, Billerica, MA). Briefly, $2 \times 10^{4}$ cells were seeded in each well (96 well plate), and once cells adhered to the surface, they were treated with STE followed by incubation with BRDU reagent for $4 \mathrm{~h}$. Absorbance was read using a spectrophotometer at 450/550 nm (Multiskan EX, Thermo Scientific, Waltham, MA). The background was subtracted from the sample values. Treated sample was normalized to untreated control sample and inhibitory effect of proliferation was expressed as a percentage to reference controls.

\subsection{RNA Isolation and Gene Expression Analysis}

At each time points after exposure to STE, cells were washed twice with PBS and lysed by adding $1 \mathrm{ml}$ of TRIzol (Invitrogen, CA) followed by isolation of RNA following manufacturer's instructions (RNeasy Qiagen). The mRNA was reverse-transcribed by using cDNA synthesis kit (iScript one-step, BioRad, CA) into cDNA and analyzed by real-time PCR (BioRad, iCycler, CA). RNA quality was assessed on Agilent Bioanalyzer (Agilent Technologies, CA). Real-Time PCR was performed using SYBR Green PCR reagents (BioRad, CA) with 100 ng of RNA and a pair of primers specific for the gene of interest. Each sample was tested in triplicate. Threshold values for target genes were normalized to beta-actin, and quantitative data was calculated using the $\Delta \Delta \mathrm{CT}$ methods [25]. The expression of 84 relevant and pathway-focused genes were evaluated in a 96-well plate using the $\mathrm{RT}^{2}$ Profiler PCR array Human Signal Transduction Pathway Finder (PAHS-014, SA Bioscience, Frederick, $\mathrm{MD}$ ) and Human apoptosis pathway (PAHS-012). Changes in cycle threshold $(\Delta \mathrm{Ct})$ values for each gene were obtained by subtracting the mean threshold cycle (Ct) of the housekeeping genes (B2M, HPRT1, RPL13A, GAPDH, ACTB) from the threshold cycle value of the gene. Normalized transcription was calculated as $2^{\wedge}$ $(-\Delta \mathrm{CT})$. The fold up- or down-regulation was calculated relative to the control by comparison of the normalized transcription of each gene. The genes that showed more than a 2-fold difference in expression were identified. Statistical analysis tools (including paired student t-test) provided by the manufacturer (SA BioSciences) with the qRT-PCR array kit was utilized to determine the level of significance in differential expression patterns. Significance was considered for genes that had $p$-value $\geq 0.05$. Three independent experiments followed by three array runs were carried out for each time point.

\subsection{Statistical Analysis}

Data were expressed as mean \pm standard deviation (SD). Statistical analysis with student's t-test was performed and the level of significance set at 0.05 (p).

\section{Results}

\subsection{Creating a Differentiated Primary Human Oral Epithelial Cell Monolayer}

Oral mucosal epithelial cells are the first line of cells to come into contact with smokeless tobacco product upon its placement in the oral cavity. This serves as a physical barrier that protects underlying cells and tissue from potential adverse effects of the products [26]. The differentiated cultures of primary oral epithelial cells were created as a way to mimic the normal physiology of oral epithelial tissue. Primary cells inherit a shorter lifespan in culture (4 - 5 passages) with loss of epithelial morphology and character after 4 to 5 passages. Therefore, we took advantage of pluripotent stem cells derived from oral tissues from human donors, which grew on cultures longer without losing their characteristic morphology. The cultures of these cells had a similar morphology to regular human oral epithelial cells (Figure 1(a)). The stage of differentiation was evaluated from the preliminary experiments both phenotypically and biochemically. Morphologically, as differentiation progressed, cells started to lose epithelial character (cobblestone appearance), but advanced into smaller, rounded shape cells with less cytoplasm and larger nuclei (Figure 1(b)). Involucrin, a differentiation marker, is expressed in the latter stage of the differentiation process in oral epithelial cells [27]. Immunohistochemically, there was a clear expression of involucrin in differentiated cells when compared to undifferentiated cells. However, a basal expression of involucrin was observed in undifferentiated cells. Further, the expression of involucrin started to appear 


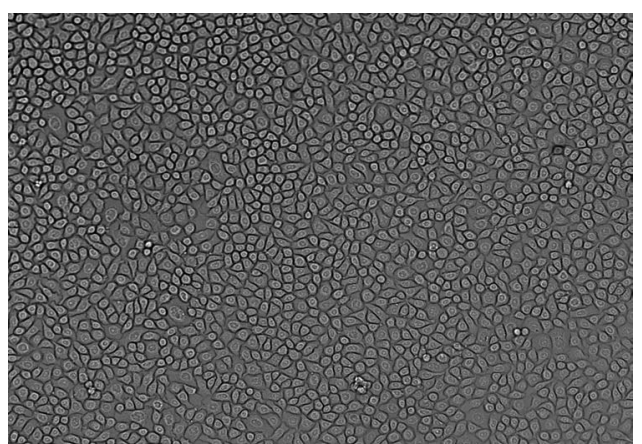

(a)

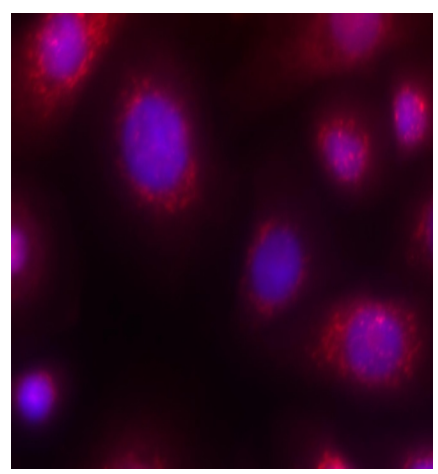

(c)
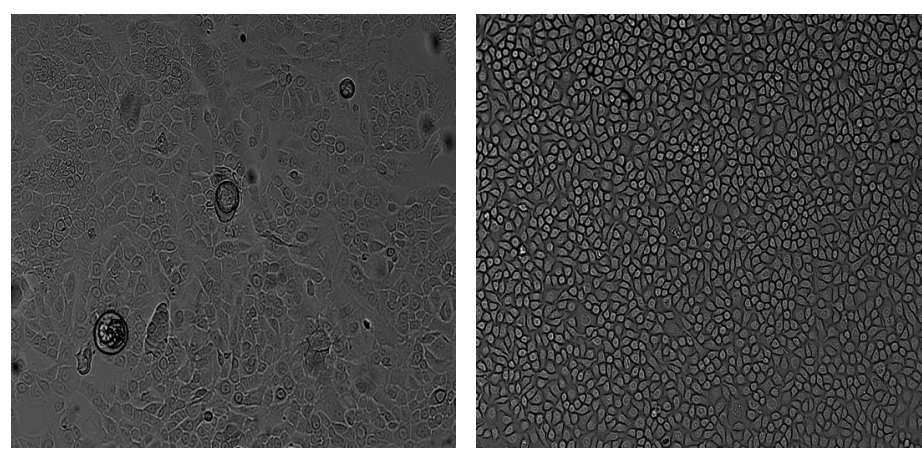

(b)

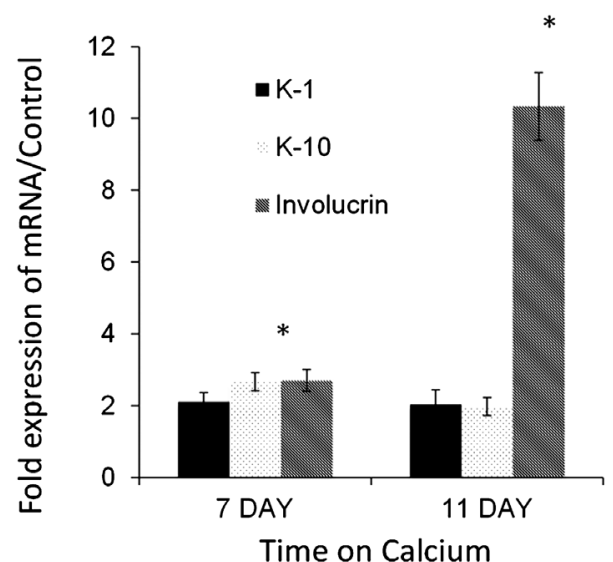

(d)

Figure 1. Creation of differentiated oral epithelial cell monolayer. (a) Characteristic appearance of epithelial cells ("cobblestone") $\times 10$. (b) Morphological difference between differentiated cells and undifferentiated cells; cells on high calcium media (left) and cells on low calcium media (right) at day $7.0 \times 10$. (c) Expression of differentiation marker, involucrin by immunofluorescence; cells on high calcium media (left), cells on low calcium media (right). (d) Expression of differentiation markers, Keratin-1, Keratin-10 and involucrin at RNA level in relative to control at day 7 and day 11 analyzed by qRT-PCR. Results represent the mean and standard deviation from three independent experiments. Asterisks indicate statistically significant differences compared to untreated $(0 \mathrm{mg} / \mathrm{ml})$ cells $(\mathrm{p} \leq 0.05)$.

as early as 3 days on calcium and further increased with time. At day 7, almost all cells showed a robust expression of involucrin in the differentiated cell population, whereas only selected cells expressed it in undifferentiated cells (Figure 1(c)). Further, we analyzed quantitatively the expression of differentiation markers such as Keratin-1, keratin-10 and involucrin at RNA level (Figure 1(d)). Two and 3 fold difference in the expression of Keratin 1 and 10 was observed compared to undifferentiated cells at day 7 and 11, respectively. Interestingly, involucrin expression was 3 times higher at day 7, whereas it was 11 times higher at day 11 in differentiated cells compared to the controls, suggesting treatment with calcium leads cells to differentiate.

\subsection{Effects of Smokeless Tobacco Extracts (STE) on Epithelial Cell Viability and Proliferation}

First, we determined whether STE affect both the viability and proliferation of oral epithelial cells at physiologically relevant doses. We chose a range of STE doses that are similar to the level of nicotine found in saliva of those who uses ST regularly as measured by nicotine concentration. Human saliva of regular ST users contained $73 \mu \mathrm{g} / \mathrm{ml}$ to $1560 \mu \mathrm{g} / \mathrm{ml}$ of nicotine [28]. Our original STE only had $1.25 \%$ of nicotine, which is equivalent to $1250 \mu \mathrm{g} / \mathrm{ml}$ of nicotine in the absolute solution (assuming complete extraction). Doses of $1 \mathrm{mg} / \mathrm{ml}(12.5 \mu \mathrm{g} / \mathrm{ml}$ of nicotine), $10 \mathrm{mg} / \mathrm{ml}(125 \mu \mathrm{g} / \mathrm{ml}$ of nicotine), and $100 \mathrm{mg} / \mathrm{ml}(1250 \mu \mathrm{g} / \mathrm{ml}$ of nicotine $)$ of STE were incubated with cells for 1 h, 3 h, $6 \mathrm{~h}$ and 24 h followed by analysis for cell viability with NR assay. Further, the range of STE concentrations ( $1 \mathrm{mg} / \mathrm{ml}$ to $100 \mathrm{mg} / \mathrm{ml}$ ) in our experiment is consistent with previous published data [26]. There was no noticeable difference in cell viability between treated and untreated control cells for $1 \mathrm{~h}$ and $3 \mathrm{~h}$ 
time points with $1 \mathrm{mg} / \mathrm{ml}$ and $10 \mathrm{mg} / \mathrm{ml}$ (Figure 2(a)). Interestingly, the viability for $6 \mathrm{~h}$ and $24 \mathrm{~h}$ was $70 \%$ and $65 \%$ with exposure to $10 \mathrm{mg} / \mathrm{ml}$, respectively. With the exposure to $100 \mathrm{mg} / \mathrm{ml}$ of smokeless tobacco, $80 \%$ viability at $3 \mathrm{~h}$ and $60 \%$ viability at $6 \mathrm{~h}$ were observed. One-hour incubation with the same dose did show any difference in the viability, whereas very low viability was seen for $24 \mathrm{~h}$ incubation (20\%). The effect of STE for cell viability was closely associated with both incubation time and dose. The dose of $10 \mathrm{mg} / \mathrm{ml}$ of STE was chosen as a dose for the following experiments based on cell viability data. Three different time points were selected for subsequent experiments as follows: $1 \mathrm{~h}$ (acute exposure), $3 \mathrm{~h}$ and $6 \mathrm{~h}$ (intermediate exposure), and 24 $\mathrm{h}$ (long term exposure).

In an effort to explore the effect of STE on cell proliferation, we incubated cells with increasing concentrations ranging from $1 \mathrm{mg} / \mathrm{ml}(1 \%)$ to $50 \mathrm{mg} / \mathrm{ml}$ (50\%) of smokeless tobacco for $6 \mathrm{~h}, 24 \mathrm{~h}$ and $48 \mathrm{~h}$. Inhibition of proliferation was analyzed by BRDU assay. Until the concentration reached $10 \mathrm{mg} / \mathrm{ml}$, there was no notable difference in the proliferation. At $6 \mathrm{~h}$ time point, STE-treated cells had $82 \%$ proliferative cells compare to control sample (Figure 2(b)). With the increase of the concentration from $10 \mathrm{mg} / \mathrm{ml}$ to $25 \mathrm{mg} / \mathrm{ml}$ and $50 \mathrm{mg} / \mathrm{ml}$, the

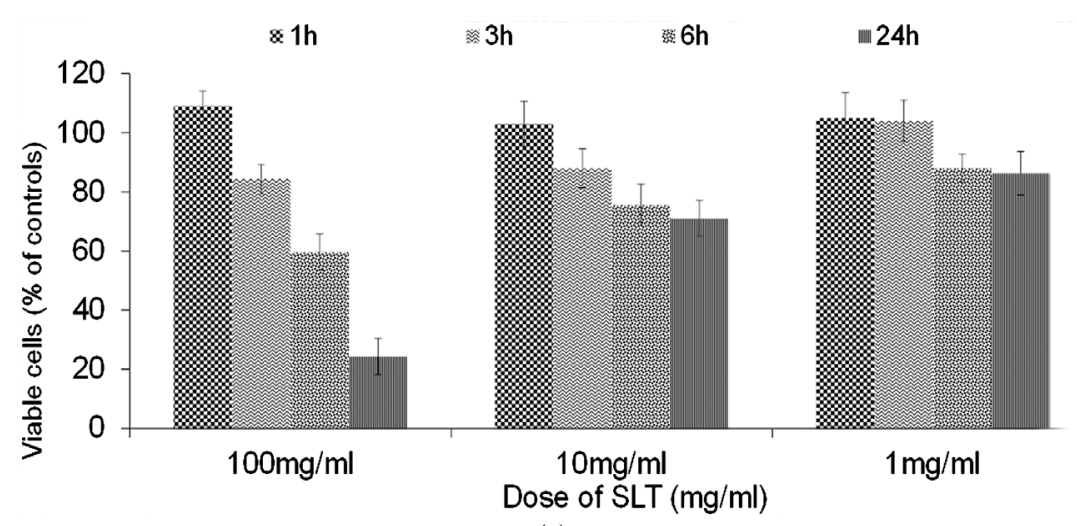

(a)

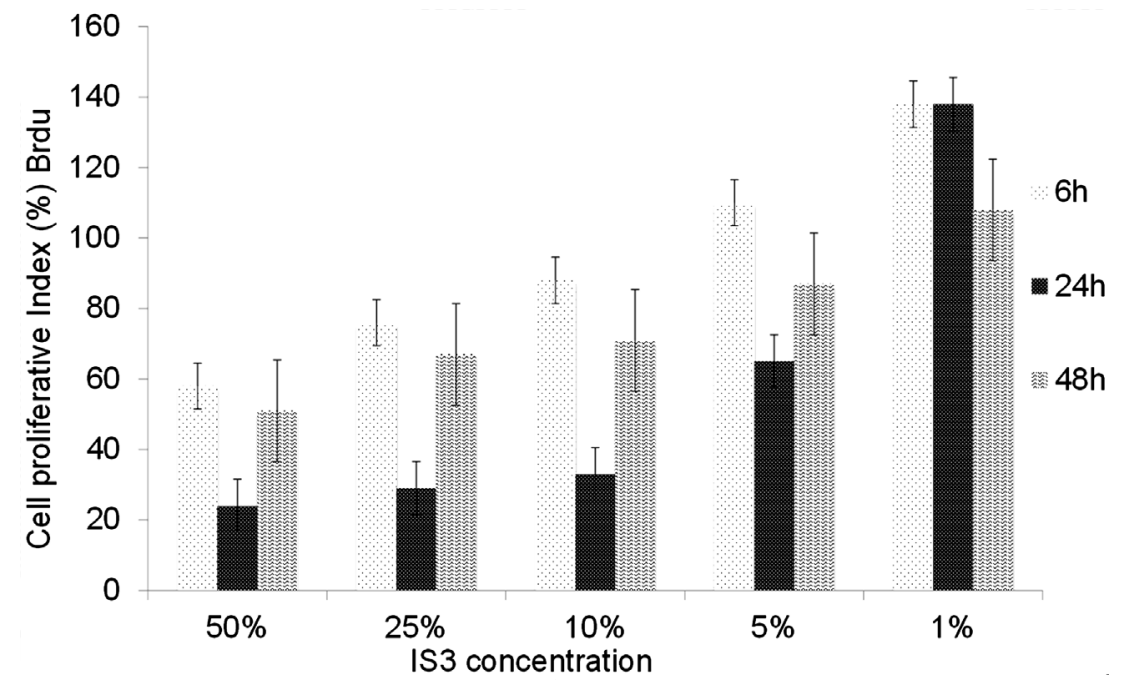

(b)

Figure 2. The effects of SLE and IS3 on HGEP cell viability and proliferation. (a) The viability of HGEP cells relative to SLE dose and time is shown. Cells were incubated with IS3 for increasing time and dose as indicated above followed by analyzed with Neutral Red Assay. Data indicate the percent of control values. Results represent the mean and standard deviation from three independent experiments (b) Effect of IS3 on the proliferation of HGEP cells. Once cells differentiated, cells exposed to increasing concentration of $1 \mathrm{~S} 3$ (range: $1 \mathrm{mg} / \mathrm{ml}(1 \%)$ to $50 \mathrm{mg} / \mathrm{ml}(50 \%)$ ) for $6 \mathrm{~h}, 24 \mathrm{~h}$ and $48 \mathrm{~h}$ followed by analyzed cell proliferation by BRDU assay as described elsewhere. Each data point represents the mean and standard deviation from three independent experiments. 
number of proliferative cells started to decline as follows; $74 \%$ and 55\%, respectively. Unlike the effect of STE on cell viability, anti-proliferative effects of STE exposure came into effect with longer incubation indicating cell viability independent effect. At $24 \mathrm{~h}$ time point, there was no visible difference in the proliferation with 1 $\mathrm{mg} / \mathrm{ml}$ dose whereas anti-proliferative effects were observed with increasing concentration of STE (68\% at 5 $\mathrm{mg} / \mathrm{ml}, 35 \%$ at $10 \mathrm{mg} / \mathrm{ml}, 25 \%$ at $25 \mathrm{mg} / \mathrm{ml}$ and $22 \%$ at $50 \mathrm{mg} / \mathrm{ml}$ ). At $48 \mathrm{~h}$ time point, no effect on proliferation was observed at $1 \mathrm{mg} / \mathrm{ml}$. A dose-related increase in the inhibition of proliferation was observed with increasing concentration of STE as follows ( $65 \%$ at $5 \mathrm{mg} / \mathrm{ml}, 35 \%$ at $10 \mathrm{mg} / \mathrm{ml}, 30 \%$ at $25 \mathrm{mg} / \mathrm{ml} \mathrm{and} 22 \%$ at $50 \mathrm{mg} / \mathrm{ml}$ ). The data here shows a dose and time dependent inhibitory effect on cell proliferation by smokeless tobacco. In conclusion, smokeless tobacco has an effect on cell viability and proliferation indicating our system is responding to the treatment.

\subsection{Effects of Smokeless Tobacco in the Expression of Genes Associated with Signal Transduction Pathway}

Having seen a time and dose dependent response to the treatment, we then wanted to dissect the mechanistic basis for the cellular response. To accomplish this, we targeted 18 different major signal transduction pathways by focusing on 84 genes. Fold differences in the expression of genes with significance were summarized for each time point (Table 1). One hour after exposure, $23.8 \%$ of genes were significantly regulated compare to controls, including genes associated with apoptosis: BAX, BCA2A1, BIRC3, and TNF (Table 2). Interestingly, most of those genes ( 9 out of 11 ) were down-regulated. Three hours after exposure, $44 \%$ of the genes were significantly regulated including cell cycle regular protein CDK2 (p33), CDKN1B (p27), and CDKN2B (p15). In contrast to $1 \mathrm{~h}$ exposure, only 5 genes were down-regulated out of 37 (32 up regulated) genes at $3 \mathrm{~h}$ exposure. After $6 \mathrm{~h}$ exposure, overall 21.4\% genes were significantly changed including BIRC3, CDK2 (p33), and VEGFA. However, only one gene, which is HOXA1, was down-regulated at this time point. However, this gene remained significantly up-regulated at $1 \mathrm{~h}$ and $3 \mathrm{~h}$ time points. With respect to long term STE exposure (24 h exposure), 28.5\% genes were significantly regulated; only 5 genes out of 24 (19 up-regulated) were down regulated. This up-regulation includes BIRC3, inflammation-associated genes such as IL-8, SELE, IL1A, and TNF- $\alpha$. Overall, pathways associate with inflammation, cell adhesion, cell cycle regulation, and apoptosis were mostly affected with the treatment. There are 8 key genes that play a vital role in inflammation that were significantly regulated with the treatment (Figure 3) including IL-8, IL-1A, LTA, MMP10, NOS2, PTGS2 (COX-2), SELPLG, and TNF- $\alpha$.

\subsection{Smokeless Tobacco Induced Apoptosis by Regulating Anti/Pro-Apoptotic Genes}

We extended this study to investigate apoptosis as data from the signal transduction pathway indicated an involvement of apoptosis-associated genes in response to smoke exposure. This was accomplished by incubating cells with the STE treatment for 6 h, $24 \mathrm{~h}$ and $48 \mathrm{~h}$. No apoptosis was seen with $6 \mathrm{~h}$ incubation. However, STE treated cells had remarkable induction of apoptosis at $24 \mathrm{~h}$ time point, as estimated by the percentage of Fluorescein positive cells compared to control cells (Figure 4). This observation remained the same for $48 \mathrm{~h}$ time point. In fact, induction of apoptosis was recently reported after exposure to STE, but the understanding on its mechanistic basis was very minimal [16] [18]). In an effort to gain more understanding of the mechanism with a particular interest on gene expression, we analyzed the apoptosis pathway by focusing on 84 genes that are closely associated with apoptosis. Consistent with the findings of our protein analysis, down-regulation of caspase-3 gene at 24 h exposure was observed. BIRC3, BNIP1, HRK, TP53BP2, TRAF3 and TRAF4 are the most notable genes with more than a two-fold difference identified (Table 3). In contrast to up-regulated genes, more genes were down-regulated over two-fold at $24 \mathrm{~h}$. Some of the prominent genes at this time point were CARD6, CASP1, CASP4, CASP6, and CASP10.

\section{Discussion}

Epidemiological studies suggest an association between the use of smokeless tobacco (ST) and occurrence of head and neck cancer. In the recent past, a number of studies highlighted the biological effects of ST, indicating its role in carcinogenesis. However, there were no previous studies conducted aimed at understanding the molecular mechanism, particularly emphasizing gene expression. Lack of a proper model system to study the biological effects of ST further prevented the progress of work in this field. Oral epithelial cells are not only the first 
Table 1. List of the 84 genes in the signal transduction pathway examined by the study. Shown is the fold difference in gene expression as a result of STE exposure relative to housekeeping genes. Gene selection was based on Human Signal Transduction Pathway Finder PCR Array kit from SA Bioscience. A description of each gene and the list of 18 transduction pathways are provided on the manufacturer's Web site. Three independent experiments were analyzed for each time point. Significant expression is indicated in red fonts.

\begin{tabular}{|c|c|c|c|c|c|c|c|c|c|}
\hline Gene & $1 \mathrm{~h}$ & $3 \mathrm{~h}$ & $6 \mathrm{~h}$ & $24 \mathrm{~h}$ & Gene & $1 \mathrm{~h}$ & $3 \mathrm{~h}$ & $6 \mathrm{~h}$ & $24 \mathrm{~h}$ \\
\hline ATF2 & 1.5 & 2.4 & 1.7 & -0.1 & IKBKB & 1.4 & 0.3 & 1.7 & -2.4 \\
\hline BAX & 1.2 & 1.6 & 1.3 & -5.8 & IL1A & -3.1 & 1.5 & 7.3 & 5.0 \\
\hline BCL2 & 5.5 & 2.3 & 1.5 & -6.5 & IL2 & 73.2 & 2.0 & 1.7 & -1.0 \\
\hline BCL2A1 & -1.9 & -4.5 & 0.7 & 2.0 & IL4 & 21.0 & 9.0 & 8.6 & -2.6 \\
\hline BCL2L1 & 0.3 & 0.1 & 2.0 & 1.5 & IL4R & 1.4 & 0.5 & -0.4 & -1.4 \\
\hline NAIP & 2.7 & 1.5 & 0.4 & -13.4 & IL8 & -1.2 & 7.4 & 36.9 & 257.2 \\
\hline BIRC2 & -0.2 & -0.3 & 1.4 & 0.9 & IRF1 & 1.4 & 3.2 & 0.5 & 1.1 \\
\hline BIRC3 & -1.7 & 3.4 & 3.4 & 7.9 & JUN & 2.4 & 5.2 & 4.2 & 2.2 \\
\hline BMP2 & 69.6 & -1.2 & 14.0 & 6.2 & KLK2 & 0.4 & 1.3 & 1.3 & -4.3 \\
\hline BMP4 & 2.0 & 6.5 & 12.7 & 0.0 & LEF1 & 0.7 & -0.7 & -1.4 & -1.7 \\
\hline BRCA1 & -0.1 & -1.2 & 0.3 & -36.2 & LEP & 1.2 & 2.0 & 1.2 & -3.2 \\
\hline CCL2 & 1.5 & 6.4 & 11.6 & -3.5 & LTA & 9.3 & 33.5 & 18.0 & -1.7 \\
\hline CCL20 & -12.2 & -5.1 & 7.5 & 43.9 & MDM2 & 1.2 & 1.6 & 2.2 & 0.1 \\
\hline CCND1 & 1.5 & 0.8 & 1.6 & -6.8 & MMP10 & -1.9 & -1.9 & 5.5 & 7.1 \\
\hline CD5 & 5.1 & 2.7 & 1.9 & -3.2 & MMP7 & 2.5 & 0.2 & 1.4 & -0.5 \\
\hline CDK2 & 0.4 & 1.5 & 2.6 & 0.0 & MYC & -0.6 & -0.4 & 2.3 & -8.6 \\
\hline CDKN1A & -1.1 & 1.0 & 2.2 & 0.3 & NFKB1 & 1.1 & 1.2 & 1.6 & 1.7 \\
\hline CDKN1B & 2.9 & 9.2 & 1.9 & 1.0 & NOS2 & 39.8 & 20.2 & 8.6 & -1.4 \\
\hline CDKN2A & 0.5 & 0.7 & 1.9 & 4.8 & NRIP1 & 1.3 & -1.0 & 3.2 & 4.3 \\
\hline CDKN2B & -0.4 & 2.3 & 3.1 & -0.3 & ODC1 & -4.0 & -3.3 & 0.8 & 2.8 \\
\hline СЕВРВ & -1.1 & 0.5 & 4.0 & 2.0 & PECAM1 & 0.6 & -1.1 & -2.2 & -2.2 \\
\hline CSF2 & 27.9 & 0.5 & 34.1 & 157.8 & PPARG & 0.4 & 0.4 & 2.2 & 2.2 \\
\hline CXCL9 & 0.4 & -1.2 & 0.4 & -3.8 & PRKCA & -1.3 & -0.4 & 0.4 & -7.4 \\
\hline CYP19A1 & 1.0 & 40.5 & -31.8 & -4.2 & PRKCE & 1.5 & 3.2 & 2.5 & -0.7 \\
\hline EGR1 & -4.4 & 13.2 & -0.5 & 0.7 & РTCH1 & 0.4 & 2.4 & 2.3 & -2.5 \\
\hline EN1 & 0.4 & 1.3 & 1.3 & -3.0 & PTGS2 & -6.0 & 1.3 & 21.7 & 25.5 \\
\hline FAS & -0.4 & -1.4 & 0.3 & -0.8 & $\mathrm{RBP1}$ & 1.6 & 1.2 & 1.3 & -1.7 \\
\hline FASLG & 0.4 & 1.5 & 0.5 & -2.9 & SELE & -2.8 & -0.8 & 0.5 & -2.9 \\
\hline FASN & 1.5 & 1.7 & 2.0 & 2.9 & SELPLG & 2.4 & 17.9 & 50.7 & 14.9 \\
\hline FN1 & 1.8 & 0.6 & 1.2 & -0.6 & TANK & -0.2 & 1.4 & 6.4 & 3.3 \\
\hline FOS & 0.4 & 8.0 & -6.1 & -1.1 & TCF7 & 1.7 & -0.2 & 2.1 & -2.6 \\
\hline FOXA2 & -1.4 & -0.4 & 5.1 & 6.7 & TERT & 0.4 & 1.3 & 1.3 & -2.9 \\
\hline GADD45A & 1.5 & 3.5 & 7.9 & 8.1 & TFRC & -1.7 & -1.6 & -0.3 & 4.2 \\
\hline GREB1 & 2.6 & 0.3 & 7.2 & -5.3 & PMEPA1 & 0.5 & -0.4 & 5.8 & 3.3 \\
\hline GYS1 & 1.4 & 1.4 & 1.5 & -8.5 & TNF & 1.9 & 22.0 & 4.5 & 37.4 \\
\hline HK2 & 2.0 & -0.5 & 1.4 & 12.0 & TP53 & 1.2 & 0.4 & 1.7 & -9.2 \\
\hline HOXA1 & 3.4 & 2.3 & -2.8 & -2.9 & ТР53I3 & 0.6 & -0.4 & -0.3 & -3.7 \\
\hline HSF1 & -0.5 & -0.3 & 1.5 & 2.7 & VCAM1 & 0.3 & 1.3 & 1.3 & -2.9 \\
\hline HSPB1 & 0.5 & 1.6 & 0.6 & -1.5 & VEGFA & -1.7 & 1.0 & 8.1 & 6.0 \\
\hline HSP90AA2 & 0.4 & -0.4 & 0.6 & -2.4 & WISP1 & 9.5 & 2.5 & -8.0 & -8.8 \\
\hline ICAM1 & 1.2 & 1.6 & 3.0 & 1.0 & WNT1 & 2.2 & -0.7 & 0.6 & -2.9 \\
\hline IGFBP3 & -2.0 & 5.9 & 23.4 & 15.0 & WNT2 & 0.4 & 1.3 & 1.3 & -2.9 \\
\hline
\end{tabular}


Table 2. Total number of genes and percentage of genes with significant changes in expression. Oral Epithelial cells were exposed to STE for $1 \mathrm{~h}, 3,3,6 \mathrm{~h}$, and $24 \mathrm{~h}$ followed by analysis of gene expression by RT-PCR array analysis as described in the Materials and Methods. Data are mean from three independent experiments.

\begin{tabular}{ccccc}
\hline & \multicolumn{3}{c}{ Time of Exposure } \\
\hline Regulation with significance & $1 \mathrm{~h}$ & $3 \mathrm{~h}$ & $6 \mathrm{~h}$ & $24 \mathrm{~h}$ \\
Number of genes & 20 & 37 & 18 & 24 \\
Percentage of genes & $23.8 \%$ & $44.0 \%$ & $21.4 \%$ & $28.5 \%$ \\
\hline
\end{tabular}

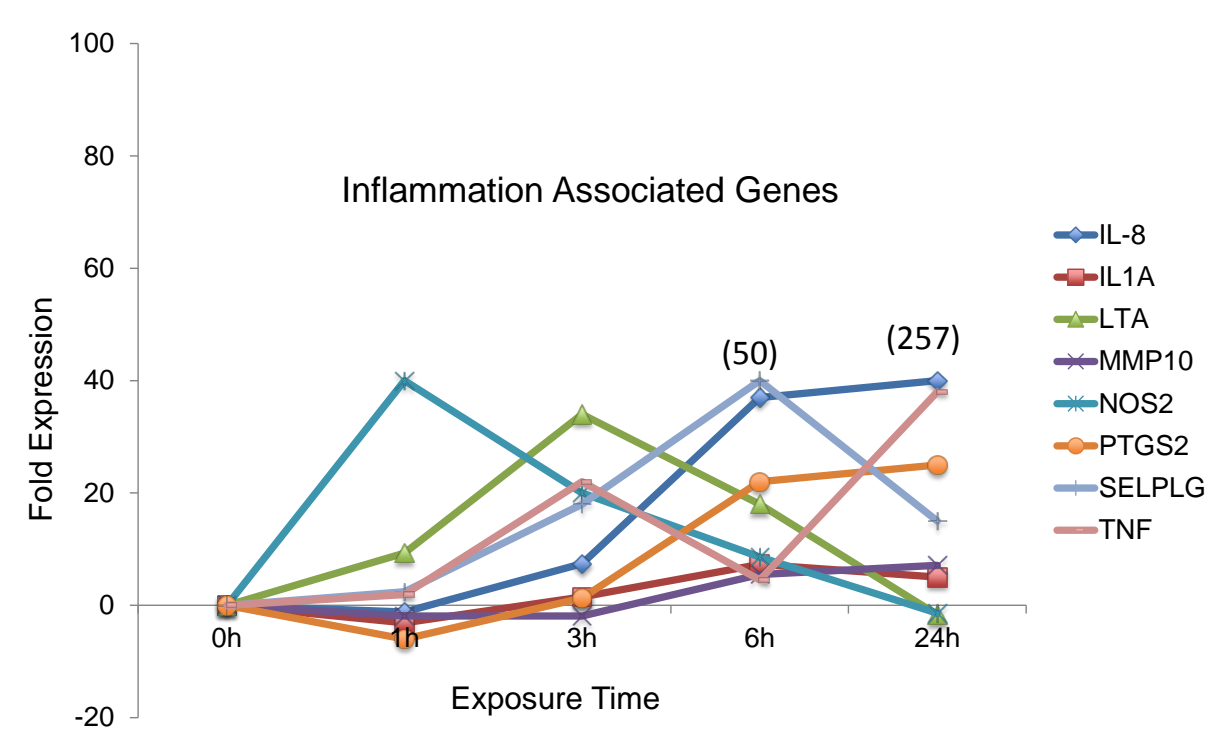

Figure 3. Expression pattern of genes associated with Inflammation. Fold expression of genes with respect to control are plotted against exposure time. Cells exposed at $10 \mathrm{mg} / \mathrm{ml}$ of $1 \mathrm{~S} 3$ for indicated time points followed by analyzed as described elsewhere. The indicated genes demonstrated significant change at least in one time point. Data represents three independent experiments.

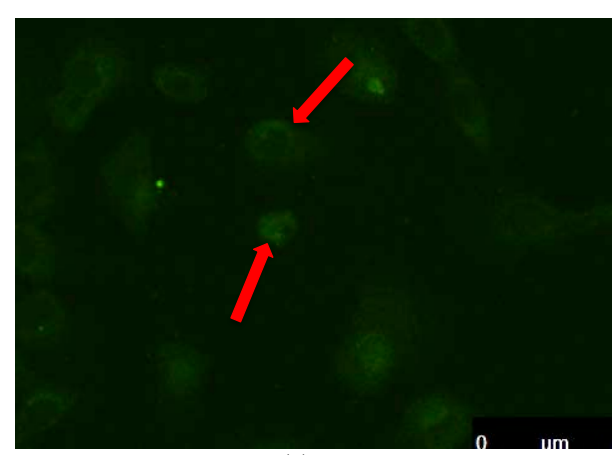

(a)

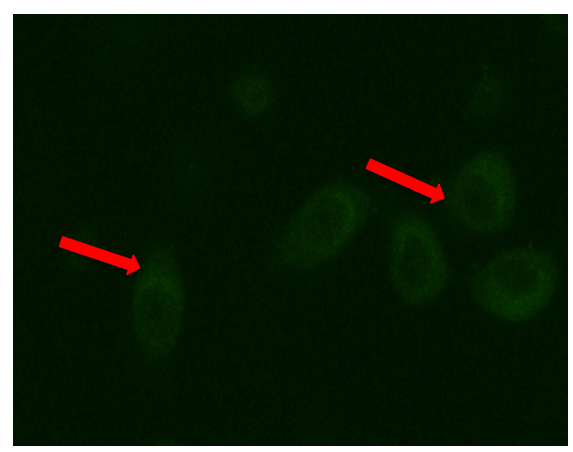

(b)

Figure 4. DNA double strand break result from IS3 exposure. HGEP cells were incubated with $1 \mathrm{~S} 3$ at the dose of $10 \mathrm{mg} / \mathrm{ml}$ for $48 \mathrm{~h}$ followed by analysis of apoptosis with TUNEL assay. The arrow indicates the TUNEL positive nuclei (apoptotic cells).

element of defense against toxicants, but they are also the most pathologically insulted tissue in the oral cavity in the event of consistent exposure to toxicants like tobacco. Therefore, this makes the most appropriate model system to study smoke induced biological effects. The reason to create a differentiated cell layer from primary oral epithelial cells was to closely mimic oral tissue. Previous studies with ST products have been conducted on monolayers of primary cells, which does not support a keratinized layer. By creating a keratinized layer, we 
Table 3. List of the 84 genes in the apoptosis examined by the study. Fold difference in the expression of gene as a result of STE exposure was shown relative to house keeping genes. Gene selection was based on apoptosis PCR Array kit from SA Bioscience. A descriptions of each gene is provided by the manufacturer and is available on their Web site. Three independent experiments were analyzed for each time point. Significant expression is indicated in red fonts.

\begin{tabular}{|c|c|c|c|c|c|}
\hline Gene & $24 \mathrm{~h}$ & Gene & $24 \mathrm{~h}$ & Gene & $24 \mathrm{~h}$ \\
\hline ABL1 & -1.1 & BNIP3 & 1.0 & GADD45A & 8.98 \\
\hline AKT1 & 1.0 & BNIP3L & 1.1 & HRK & 2.70 \\
\hline APAF1 & 1.6 & BRAF & -1.3 & IGF1R & -1.32 \\
\hline $\mathrm{BAD}$ & 3.2 & NOD1 & -1.3 & LTA & 2.58 \\
\hline BAG1 & -2.1 & CARD6 & -5.8 & LTBR & -1.02 \\
\hline BAG & 1.7 & CARD8 & -8.0 & MCL1 & 1.91 \\
\hline BAG4 & 2.4 & CASP1 & -5.3 & NOL3 & -11.58 \\
\hline BAK1 & 5.3 & CASP10 & -4.8 & PYCARD & -4.00 \\
\hline BAX & -2.7 & CASP14 & -7.6 & RIPK2 & 2.83 \\
\hline BCL10 & 2.1 & CASP2 & 1.7 & TNF & 9.62 \\
\hline BCL2 & -1.7 & CASP3 & -1.5 & TNFRSF10A & 3.56 \\
\hline BCL2A1 & -1.2 & CASP4 & -4.0 & TNFRSF10B & 3.56 \\
\hline BCL2L1 & 8.8 & CASP5 & 1.2 & TNFRSF11B & -1.74 \\
\hline BCL2L10 & -2.4 & CASP6 & -2.2 & TNFRSF1A & -1.02 \\
\hline BCL2L11 & -2.0 & CASP7 & -1.59 & TNFRSF21 & -1.78 \\
\hline BCL2L2 & 1.6 & CASP8 & -9.62 & TNFRSF25 & 1.55 \\
\hline BCLAF1 & 1.1 & CASP9 & -1.48 & CD27 & -1.20 \\
\hline BFAR & 1.0 & CD40 & 1.74 & TNFRSF9 & 2.30 \\
\hline BID & -3.2 & CD40LG & 1.23 & TNFSF10 & -12.13 \\
\hline BIK & 1.2 & CFLAR & 1.48 & CD70 & 7.64 \\
\hline NAIP & -3.6 & CIDEA & -1.38 & TNFSF8 & 1.55 \\
\hline BIRC2 & 1.0 & CIDEB & -1.35 & TP53 & -6.96 \\
\hline BIRC3 & 12.1 & CRADD & 1.10 & ТР53ВР2 & 3.17 \\
\hline XIAP & 1.3 & DAPK1 & -1.18 & TP73 & -1.52 \\
\hline BIRC6 & -2.8 & DFFA & -2.76 & TRADD & -2.19 \\
\hline BIRC8 & 1.1 & FADD & -3.82 & TRAF2 & 3.03 \\
\hline BNIP1 & 3.3 & FAS & -2.83 & TRAF3 & 3.33 \\
\hline BNIP2 & 1.9 & FASLG & 1.45 & TRAF4 & 7.82 \\
\hline
\end{tabular}

expected cells to act and respond in a more pathologically and physiologically similar manner to oral tissue of the smoker. In this study, we look into transcriptional changes as a result of exposure of oral epithelial cells to STE.

In the acute phase of exposure, marked reduction in gene expression suggested a cessation of many cellular activities. At this time, the majority of regulated genes were down-regulated. Interestingly, the same observation was recently seen when cigarette smoke was introduced into differentiated bronchial epithelial cells [29]. The evaluation of a set of relevant genes involved in biological pathways provides more meaningful and comprehen- 
sive analysis than assessing gene by single basis. Analyzing the effect of STE on 18 different signal transduction pathways provided valuable targets that help us understand the mechanistic basis of the effect. ST is composed of a complex mixture of ingredients including 23 different carcinogenic substances. Some of the composites such as polycyclic aromatic hydrocarbons (PAH) and nitrosamines have multiple effects on various genes in the system [30]. This explains the significance of analyzing the genes as a group rather than on an individual basis.

The cell cycle regulatory proteins such as CDK2 (p33), CDKN1B (p27), and CDKN2B (p15) are implicated in the disease process of oral cancer [31]-[33]. Exposure to STE significantly altered the expression of the genes encoding these proteins, particularly in the early phase of exposure. Induction of cell cycle regulatory proteins may have led to increased cell proliferation (short time incubation). With higher concentration, anti-proliferative effects dictated, with no significant change in the up regulation of cell cycle regulatory genes. Therefore, STE induces cell proliferation at lower doses, whereas higher concentrations had an anti-proliferative effect. Interestingly, consistent with our observation, Rohatgi et al. recently reported an induction of proliferation with lower concentration and inhibitory effect with higher concentration [22]. AP-1, a transcription factor comprised primarily of c-JUN and Fos family protein regulates gene involved in cell proliferation in epithelial cells [34]. Induction of c-JUN and Fos in this study may partly be linked with induction of cell proliferation with low dose of STE.

Genes associated with the PI3K/Akt pathway such as Bcl-2, FNI, c-JUN, MMP-7, and MYC were significantly up regulated during the course of the experiments This suggests a possible activation of the pathway as a response to the treatment. The same gene activation was observed when cancer cell lines derived from head and neck cancer patients were exposed to STE [35]. Nicotine, one of the major components of STE can induce the PI3K/Akt pathway [36]. However, we cannot confirm that the activation of the Akt pathway by smokeless tobacco in our study is directly/indirectly linked with nicotine. Molecules that inhibit activation of PI3K/Akt pathway are likely to have the potential for prevention of ST-induced health risk. COX-2, a pro-inflammatory gene is associated with the early stages of tumorgenesis. Recent studies have shown that ST exposure on oral epithelial cells results in up-regulation of COX-2 [8]. In light of this knowledge, expression of COX-2 in our study might have a role in carcinogenesis.

Inflammation associated genes in addition to COX-2 such as SELPLG, IL-8, TNF-a, and IL-1a were significantly up regulated in response to smokeless tobacco exposure, suggesting a role in inflammation. Recently, when human bronchial epithelial cells were exposed to cigarette smoke, an up regulation of IL-8, SELPLG, MMP10 and LTA was observed [24].

A number of reports suggest that smokeless tobacco-induced toxicity in various oral cell types including hamster cheek pouch cells, primary culture of keratinocytes, and EBV-infected B cells is mediated through the induction of apoptosis [37]. Mechanistically, the induction of apoptosis as a result of STE exposure was suggested to be associated with the modulation of nitric oxide [18], oxidative stress [16], and osmotic stress [37]. Components in STE are implicated in the activation of Cytochrome-c, an activator of the intrinsic pathway of apoptosis, with the production of superoxide anions [16]. Further, production of reactive nitrogen species (ROS) and nitric oxide (NO) following exposure to STE was described [38]. We did not analyze the ROS and anions in our system, but we speculate that oxidative stress is more likely the mechanism that leads to promoting apoptosis through ROS and/or with anions. This is further supported by findings of significant up regulation of NOS2 (nitric oxide synthase), which helps synthesize NO (nitric oxide) at the RNA level as a result of STE exposure in our system (40 to 20 times higher production with significance compare to control at $1 \mathrm{~h}$ and $3 \mathrm{~h}$ respectively). We were unable to see any apoptotic induction with the treatment before $24 \mathrm{~h}$ at the protein level. This finding is in line with a report that showed that induction of apoptosis with the same product (1S3) started from $48 \mathrm{~h}$ and remained as so until $96 \mathrm{~h}$ suggesting STE induced apoptosis is a late event [18].

In summary, in this study, a set of biologically relevant genes was examined by qRT-PCR array analysis to generate comprehensive information for potential biomarkers. Our data indicate that the active exposure of differentiated oral epithelial cells to STE leads cells to express gene profiles for specific signal transduction pathways in a time and dose dependent manner. Signaling pathways involving cell cycle regulation, apoptosis, cellcell adhesion, and inflammation were modulated with the treatment. Data presented here are more consistent with reports demonstrating that STE can induce the Akt pathway and modify cellular function. Although these observations are promising, studies are under way to see the extent of phosphorylation of those gene that are regulated in this experiment as a way to further understand the effect of smokeless tobacco on oral epithelial cells at the protein level. These studies provide the basis for mare detailed analysis into the underlying mechanisms 
by which STE affects cellular activities. More importantly they provide a foundation upon which to determine which of the individual constituents in complex STE are differentially responsible for pathway activation. This type of information is extremely important in studies aimed at reducing the exposure risk of ST users in in absence of complete cessation of tobacco product use.

\section{Acknowledgements}

We thank Tatiana Kotova for technical support. We also thank Mark Lawson, Shom Paul and Aaron Mackey for their assistance in the computational analysis. This project was supported in whole or in part by a gift provided to the University of Virginia by Altria (Philip Morris USA). The review and approval process was overseen by an External Advisory Committee without any affiliation with the University, Altria, or any other tobacco company. Funding for this project was based upon independent intramural and extramural reviews.

\section{References}

[1] Moore, S.R., Johnson, N.W., Pierce, A.M. and Wilson, D.F. (2000) The Epidemiology of Mouth Cancer: A Review of Global Incidence. Oral Diseases, 6, 65-74. http://dx.doi.org/10.1111/j.1601-0825.2000.tb00104.x

[2] Proia, N.K., Paszkiewicz, G.M., Nasca, M.A., Franke, G.E. and Pauly, J.L. (2006) Smoking and Smokeless Tobacco-Associated Human Buccal Cell Mutations and Their Association with Oral Cancer-A Review. Cancer Epidemiology, Biomarkers \& Prevention, 15, 1061-1077. http://dx.doi.org/10.1158/1055-9965.EPI-05-0983

[3] Warnakulasuriya, S. (2004) Smokeless Tobacco and Oral Cancer. Oral Diseases, 10, 1-4. http://dx.doi.org/10.1046/j.1354-523X.2003.00975.x

[4] Yatsuya, H. and Folsom, A.R. (2010) Risk of Incident Cardiovascular Disease among Users of Smokeless Tobacco in the Atherosclerosis Risk in Communities (ARIC) Study. American Journal of Epidemiology, 172, 600-605. http://dx.doi.org/10.1093/aje/kwq191

[5] Benowitz, N.L., Porchet, H., Sheiner, L. and Jacob, P. (1988) Nicotine Absorption and Cardiovascular Effects with Smokeless Tobacco Use: Comparison with Cigarettes and Nicotine Gum. Clinical Pharmacology and Therapeutics, 44, 23-28. http://dx.doi.org/10.1038/clpt.1988.107

[6] Boffetta, P., Hecht, S., Gray, N., Gupta, P. and Straif, K. (2008) Smokeless Tobacco and Cancer. The Lancet Oncology, 9, 667-675. http://dx.doi.org/10.1016/S1470-2045(08)70173-6

[7] Hergens, M. P. et al. (2007) Long-Term Use of Swedish Moist Snuff and the Risk of Myocardial Infarction amongst Men. Journal of Internal Medicine, 262, 351-359. http://dx.doi.org/10.1111/j.1365-2796.2007.01816.x

[8] Vishwanatha, J.K., Swinney, R. and Banerjee, A.G. (2003) Modulation of Annexin I and Cyclooxygenase-2 in Smokeless Tobacco-Induced Inflammation and Oral Cancer. Molecular and Cellular Biochemistry, 248, 67-75. http://dx.doi.org/10.1023/A:1024153431272

[9] Hergens, M.P., Lambe, M., Pershagen, G., Terent, A. and Ye, W. (2008) Smokeless Tobacco and the Risk of Stroke. Epidemiology, 19, 794-799. http://dx.doi.org/10.1097/EDE.0b013e3181878b33

[10] Boffetta, P. and Straif, K. (2009) Use of Smokeless Tobacco and Risk of Myocardial Infarction and Stroke: Systematic Review with Meta-Analysis. BMJ, 339, b3060. http://dx.doi.org/10.1136/bmj.b3060

[11] Persson, P.G., Carlsson, S., Svanström, L., Östenson, C.G., Efendic, S. and Grill, V. (2000) Cigarette Smoking, Oral Moist Snuff Use and Glucose Intolerance. Journal of Internal Medicine, 248, 103-110. http://dx.doi.org/10.1046/j.1365-2796.2000.00708.x

[12] Samal, I.R., Maneesh, M. and Chakrabarti, A. (2006) Evidence for Systemic Oxidative Stress in Tobacco Chewers. Scandinavian Journal of Clinical and Laboratory Investigation, 66, 517-522. http://dx.doi.org/10.1080/00365510600844747

[13] Petro, T.M. (2003) Modulation of IL-12 p35 and p40 Promoter Activity by Smokeless Tobacco Extract Is Associated with an Effect upon Activation of NF- $\mathrm{B}$ but Not IRF Transcription Factors. International Immunopharmacology, 3, 735-745. http://dx.doi.org/10.1016/S1567-5769(03)00074-2

[14] Furie, M.B., Raffanello, J.A., Gergel, E.I., Lisinski, T.J. and Horb, L.D. (2000) Extracts of Smokeless Tobacco Induce Pro-Inflammatory Changes in Cultured Human Vascular Endothelial Cells. Immunopharmacology, 47, 13-23. http://dx.doi.org/10.1016/S0162-3109(99)00181-2

[15] Banerjee, A.G., Gopalakrishnan, V.K. and Vishwanatha, J.K. (2007) Inhibition of Nitric Oxide-Induced Apoptosis by Nicotine in Oral Epithelial Cells. Molecular and Cellular Biochemistry, 305, 113-121. http://dx.doi.org/10.1007/s11010-007-9534-2

[16] Bagchi, M., Balmoori, J., Bagchi, D., Ray, S.D., Kuszynski, C. and Stohs, S.J. (1999) Smokeless Tobacco, Oxidative 
Stress, Apoptosis, and Antioxidants in Human Oral Keratinocytes. Free Radical Biology \& Medicine, 26, 992-1000. http://dx.doi.org/10.1016/S0891-5849(98)00286-X

[17] Jenson, H.B., Baillargeon, J., Heard, P. and Moyer, M.P. (1999) Effects of Smokeless Tobacco and Tumor Promoters on Cell Population Growth and Apoptosis of B Lymphocytes Infected with Epstein-Barr Virus Types 1 and 2. Toxicology and Applied Pharmacology, 160, 171-182. http://dx.doi.org/10.1006/taap.1999.8766

[18] Mangipudy, R.S. and Vishwanatha, J.K. (1999) Role of Nitric Oxide in the Induction of Apoptosis by Smokeless Tobacco Extract. Molecular and Cellular Biochemistry, 200, 51-57. http://dx.doi.org/10.1023/A:1006985700851

[19] Mishra, R. and Das, B.R. (2005) Activation of STAT 5-cyclin D1 Pathway in Chewing Tobacco Mediated Oral Squamous Cell Carcinoma. Molecular Biology Reports, 32, 159-166. http://dx.doi.org/10.1007/s11033-005-0754-9

[20] Mishra, R. and Das, B.R. (2009) Cyclin D1 Expression and Its Possible Regulation in Chewing Tobacco Mediated Oral Squamous Cell Carcinoma Progression. Archives of Oral Biology, 54, 917-923. http://dx.doi.org/10.1016/j.archoralbio.2009.07.003

[21] Nagpal, J.K., Mishra, R. and Das, B.R. (2002) Activation of Stat-3 as One of the Early Events in Tobacco Chewing-Mediated Oral Carcinogenesis. Cancer, 94, 2393-2400. http://dx.doi.org/10.1002/cncr.10499

[22] Rohatgi, N., Kaur, J., Srivastava, A. and Ralhan, R. (2005) Smokeless Tobacco (Khaini) Extracts Modulate Gene Expression in Epithelial Cell Culture from an Oral Hyperplasia. Oral Oncology, 41, 806-820. http://dx.doi.org/10.1016/j.oraloncology.2005.04.010

[23] Sawhney, M., Rohatgi, N., Kaur, J., Shishodia, S., Sethi, G., Gupta, S.D., et al. (2007) Expression of NF-кB Parallels COX-2 Expression in Oral Precancer and Cancer: Association with Smokeless Tobacco. International Journal of Cancer, 120, 2545-2556. http://dx.doi.org/10.1002/ijc.22657

[24] Parsanejad, R., Fields, W.R., Morgan, W.T., Bombick, B.R. and Doolittle, D.J. (2008) The Time Course of Expression of Genes Involved in Specific Pathways in Normal Human Bronchial Epithelial Cells Following Exposure to Cigarette Smoke. Experimental Lung Research, 34, 513-530. http://dx.doi.org/10.1080/01902140802271826

[25] Livak, K.J. and Schmittgen, T.D. (2001) Analysis of Relative Gene Expression Data Using Real-Time Quantitative PCR and the 2(- $\Delta \Delta \mathrm{C}(\mathrm{T}))$ Method. Methods, 25, 402-408. http://dx.doi.org/10.1006/meth.2001.1262

[26] Mitchell, C., Joyce, A.R., Piper, J.T., McKallip, R.J. and Fariss, M.W. (2010) Role of Oxidative Stress and MAPK Signaling in Reference Moist Smokeless Tobacco-Induced HOK-16B Cell Death. Toxicology Letters, 195, 23-30. http://dx.doi.org/10.1016/j.toxlet.2010.02.020

[27] Gibbs, S. and Ponec, M. (2000) Intrinsic Regulation of Differentiation Markers in Human Epidermis, Hard Palate and Buccal Mucosa. Archives of Oral Biology, 45, 149-158. http://dx.doi.org/10.1016/S0003-9969(99)00116-8

[28] Hoffmann, D. and Adams, J.D. (1981) Carcinogenic Tobacco-Specific N-Nitrosamines in Snuff and in the Saliva of Snuff Dippers. Cancer Research, 41, 4305-4308.

[29] Maunders, H., Patwardhan, S., Phillips, J., Clack, A. and Richter, A. (2007) Human Bronchial Epithelial Cell Transcriptome: Gene Expression Changes Following Acute Exposure to Whole Cigarette Smoke in Vitro. American Journal of Physiology-Lung Cellular and Molecular Physiology, 292, L1248-L1256. http://dx.doi.org/10.1152/ajplung.00290.2006

[30] Cogliano, V., Straif, K., Baan, R., Grosse, Y., Secretan, B. and El Ghissassi, F., WHO International Agency for Research on Cancer (2004) Smokeless Tobacco and Tobacco-Related Nitrosamines. The Lancet Oncology, 5, 708. http://dx.doi.org/10.1016/S1470-2045(04)01633-X

[31] Zhang, J.T., Wang, D.W., Li, Q.X., Zhu, Z.L., Wang, M.W., Cui, D.S., et al. (2008) Nuclear to Cytoplasmic Shift of p33(ING1b) Protein from Normal Oral Mucosa to Oral Squamous Cell Carcinoma in Relation to Clinicopathological Variables. Journal of Cancer Research and Clinical Oncology, 134, 421-426. http://dx.doi.org/10.1007/s00432-007-0305-y

[32] Perisanidis, C., Perisanidis, B., Wrba, F., Brandstetter, A., El Gazzar, S., Papadogeorgakis, N., et al. (2012) Evaluation of Immunohistochemical Expression of p53, p21, p27, Cyclin D1, and Ki67 in Oral and Oropharyngeal Squamous Cell Carcinoma. Journal of Oral Pathology \& Medicine, 41, 40-46. http://dx.doi.org/10.1111/j.1600-0714.2011.01071.x

[33] Chang, H.W., Ling, G.S., Wei, W.I. and Yuen, A.P. (2004) Smoking and Drinking Can Induce p15 Methylation in the Upper Aerodigestive Tract of Healthy Individuals and Patients with Head and Neck Squamous Cell Carcinoma. Cancer, 101, 125-132. http://dx.doi.org/10.1002/cncr.20323

[34] Maritz, M.F., van der Watt, P.J., Holderness, N., Birrer, M.J. and Leaner, V.D. (2011) Inhibition of AP-1 Suppresses Cervical Cancer Cell Proliferation and Is Associated with p21 Expression. Biological Chemistry, 392, 439-448. http://dx.doi.org/10.1515/bc.2011.036

[35] Macha, M.A., Matta, A., Chauhan, S.S., Siu, K.W. and Ralhan, R. (2011) Guggulsterone Targets Smokeless Tobacco Induced PI3K/Akt Pathway in Head and Neck Cancer Cells. PLoS ONE, 6, e14728. http://dx.doi.org/10.1371/journal.pone.0014728 
[36] Zhang, J., Kamdar, O., Le, W., Rosen, G.D. and Upadhyay, D. (2009) Nicotine Induces Resistance to Chemotherapy by Modulating Mitochondrial Signaling in Lung Cancer. American Journal of Respiratory Cell and Molecular Biology, 40, 135-146. http://dx.doi.org/10.1165/rcmb.2007-0277OC

[37] Lombard, C., Farthing, D., Sun, J., Fariss, M.W. and McKallip, R.J. (2010) Reference Moist Smokeless TobaccoInduced Apoptosis in Human Monocytes/Macrophages Cell Line MM6. International Immunopharmacology, 10, 1029-1040. http://dx.doi.org/10.1016/j.intimp.2010.06.002

[38] Bagchi, M., Bagchi, D. and Stohs, S.J. (1996) In Vitro Effects of a Smokeless Tobacco Extract on the Production of Reactive Oxygen Species by Human Oral Epidermal Cells and Rat Hepatic Mitochondria and Microsomes, and Peritoneal Macrophages. Archives of Environmental Contamination and Toxicology, 30, 418-422.

http://dx.doi.org/10.1007/BF00212303 
Scientific Research Publishing (SCIRP) is one of the largest Open Access journal publishers. It is currently publishing more than 200 open access, online, peer-reviewed journals covering a wide range of academic disciplines. SCIRP serves the worldwide academic communities and contributes to the progress and application of science with its publication.

Other selected journals from SCIRP are listed as below. Submit your manuscript to us via either submit@scirp.org or Online Submission Portal.
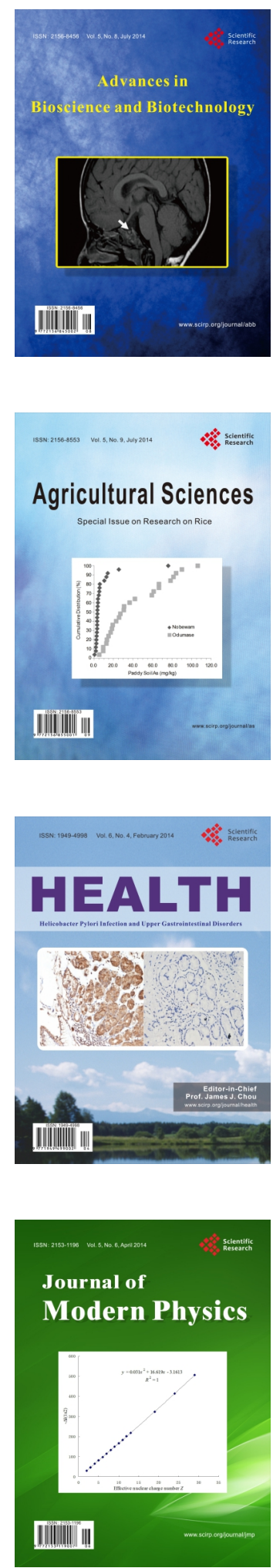
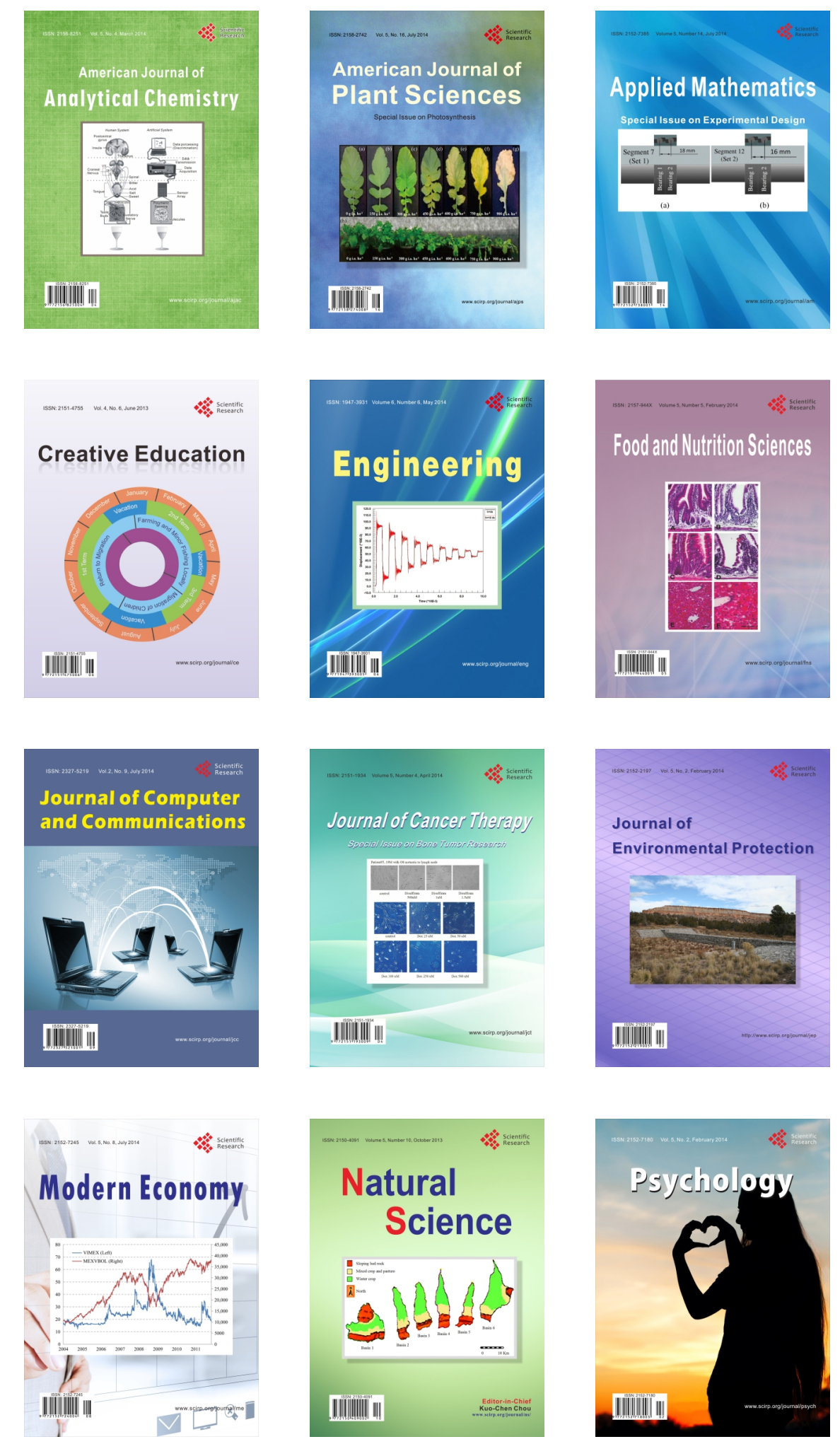